\title{
Seed Dormancy and Germination of Echinochloa oryzicola VASING. : An Observation through Respiration and Several Enzyme Activities
}

\author{
Yuji Yamasue*, Kunikazu UeKi* and Hideo Chisaka**
}

* Weed Science Laboratory, Faculty of Agriculture, Kyoto University, Kyoto 606.

** Agriculture, Forestry and Fisheries Research Council Secreratiat, Ministry of Agriculture, Forestry and Fisheries, Tokyo 100.

\section{Introduction}

Persistence of annual weeds is often related to a large number of the dormant seeds buried in soil. Dormancy enables weeds to survive and maintain the longevity as a seed bank in soil despite frequent soil disturbances and weedings. It is indicated that dormancy is the single most important characteristic of weeds which enables them to persist and flourish, and germination is critical in establishment of weed infestation (NAS, 1968). Ecological behaviors of many weeds such as the possession of seed dormancy, germination requirements, periodicity of germination and its relationship with environmental stimuli suit the purpose for their establishment and propagation at their habitats, and these are often theoretically defined as adaptation. However, our physiological and biochemical understanding of such ecological adaptation of weeds is not limited only to scientific interest, but is also important for a new approach in herbicide technology and control measures.

Echinochloa oryzicola VASING. is a gramineous and representative rice paddy weed that produces large seeds (spikelets), 3 to $5 \mathrm{mg}$ per seed, with innate or primary dormancy. The seed dormancy in fields was suggested to be terminated with the low temperatures from the late autumn to early spring, the fluctuating temperatures in spring and with the flooding that accompanied the beginning of rice cultivation (Miyahara, 1972). Seeds awakening from dormancy can germinate under oxygen-deficient conditions (MIYAhara, 1972 ; KATAOKA and Kim, 1978 ; KenNedy et al., 1980). and an anaerobic condition actually stimulates germination of seeds with relatively shallow dormancy (Yamasue and UeKI, 1979). The seed dormancy could be artificially broken with respiratory inhibitors such as $\mathrm{KCN}$ and $\mathrm{NaN}_{3}$ (Shimizu and UeKI, 1972). These combined findings indicate the importance of respiration- and/or oxygen-related reactions in the physiological mechanism of the dormancy and germination of seeds which germinate in fields flooded with paddy water.

This paper reports the first part of a series of experiments made to elucidate the ecophysiological mechanisms of seed dormancy and germination of Echinochloa oryzicola. Specific objective of the experiments reported here was to characterize the dormant and non-dormant seeds in respiration and its related enzyme activity during the imbibition under an optimum germination condition.

* A part of the experimental results reported herein was presented at the 23rd Annual Conference of the Weed Science Society of Japan in 1984. 

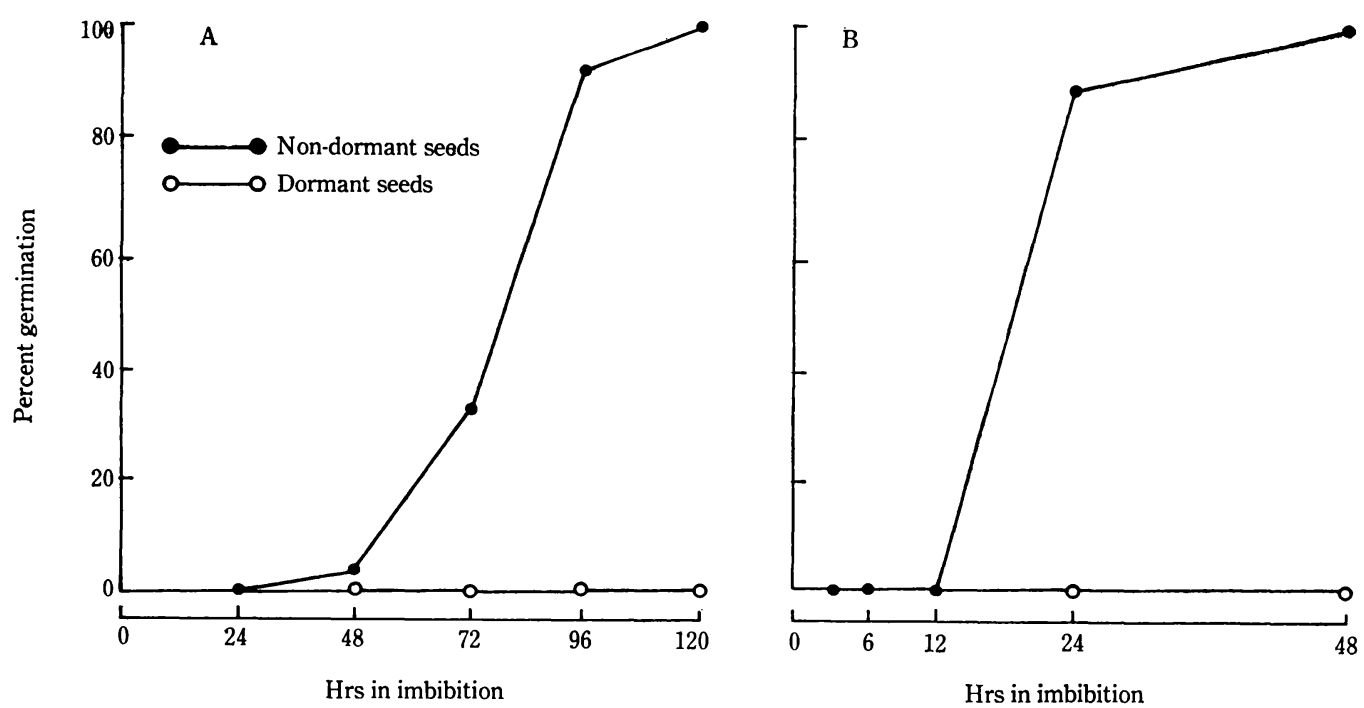

Fig. 1. Percent germination of the dormant and non-dormant seeds of Echinochloa oryzicola used for the respiration measurement (A) and for the enzyme extraction (B).

\section{Materials and Methods}

Plant Material. Dormant and non-dormant seeds were obtained from the same uniformly inbred line of Echinochloa oryzicola grown in the experimental field of Kyoto University. This line was originated from one individual plant collected at the Konosu Branch Station of the National Agricultural Research Center. The dormant seeds were those stored under a dry condition at $-21^{\circ} \mathrm{C}$ after harvesting, and the non-dormant seeds were prepared, as described by Miyahara (1972), by incubating the dormant seeds in flooded soil at $4^{\circ} \mathrm{C}$ for several months. Figure 1 shows the germination pattern of the seeds used for the respiration measurement and enzyme extraction. Data were the mean of duplicated 150-seed samples imbibed at $30^{\circ} \mathrm{C}$ in the light.

Respiration Measurement. Pattern of the change of the dormant and non-dormant seeds in respiration was determined in air with a manometric method using $\mathrm{O}_{2}$-Uptester $\mathrm{C}$ (Taiyo Sci. Inc. Co., Ltd.). One hundred and fifty seeds were sterilized with $2 \% \mathrm{NaOCl}$ for $10 \mathrm{~min}$, rinsed thoroughly with distilled water and imbibed with $5 \mathrm{ml}$ of distilled water in $6-\mathrm{cm}$ petri dish under the germination condition at $30^{\circ} \mathrm{C}$ in the light. The $\mathrm{O}_{2} / \mathrm{CO}_{2}$ exchange was measured at $3,6,12,24,54$ and $72 \mathrm{hr}$ after the beginning of imbibition. Data were the mean of duplicated measurements.

Preparation of Enzyme Extracts. The following procedure was used for all the enzyme extracts. Two hundreds of both dormant and non-dormant seeds, which had been fully imbibed at $4^{\circ} \mathrm{C}$, were sterilized and imbibed at $30^{\circ} \mathrm{C}$ under the above procedure, and sampled at $0,3,6$, 12,24 and $48 \mathrm{hr}$. The samples were homogenized in $3.1 \mathrm{ml}$ of cold extraction medium with Polytron (Kinematica, Switzerlant) at full speed for about 45 sec. with cooling by ice bath. The extraction medium contained $0.1 \mathrm{M}$ potassium phosphate buffer $(\mathrm{pH} 7.2$ ), $10 \mu \mathrm{l}$ of Triton X-100 and $200 \mathrm{mg}$ of polyvinylpolypyrolidone. The homogenate was centrifuged at $32,000 \mathrm{xg}$ for $30 \mathrm{~min}$. The resulting supernatant was adjusted to $35 \%$ (v/v) glycerine with $75 \%$ glycerine solution and stored at $-85^{\circ} \mathrm{C}$ as the crude enzyme solution until enzyme assays.

Enzyme Assays. Enzymes assayed with the 
crude enzyme solution were glucose-6-phosphate dehydrogenase (EC 1.1.1.49), 6-phosphogluconate dehydrogenase (EC 1.1.1,43), alcohol dehydrogenase (EC 1.1.1.1), isocitrate dehydrogenase (EC 1.1.1.42), cytochrome c oxidase (EC 1.9.3.1), polyphenol oxidase (EC 1.10.3.1), catalase (EC 1.11.1.6) and peroxidase (EC 1.11.1.7). Activities of glucose-6phosphate dehydrogenase and 6-P-phosphogluconate dehydrogenase were determined by the rate of reduction of NADP measured by $A_{340}$. Three assays were carried out, the first containing $50 \mathrm{mM}$ Tris- $\mathrm{HCl}(\mathrm{pH}$ 7.6), $5 \mathrm{mM}$ $\mathrm{MgCl}_{2}, \quad 0.3 \mathrm{mM}$ Glucose-6-P, $0.3 \mathrm{mM}$ 6-Pgluconate, $0.2 \mathrm{mM}$ NADP and $50 \mu$ l enzyme extract in $3 \mathrm{ml}$. The second contained all the above except glucose-6-P, and the third contained only the buffer and $50 \mu l$ enzyme extract. The difference in the reduction rate of NADP between the first and second assays was used to calculate glucose-6-phosphate dehydrogenase activity, and the difference between the second and third assays was used for 6-phosphogluconate dehydrogenase. Activity of alcohol dehydrogenase was determined by the rate of reduction of NAD in the $3 \mathrm{ml}$ assay medium containing $200 \mathrm{mM}$ Tris- $\mathrm{HCl}$ ( $\mathrm{pH} \mathrm{8.5)}$ ), $0.3 \mathrm{mM}$ NAD, $17 \mathrm{mM}$ ethanol and $100 \mu \mathrm{l}$ enzyme extract.

Isocitrate dehydrogenase activity was also determined by reduction of NADP. Two assays were carried out, one containing $50 \mathrm{mM}$ Tris$\mathrm{HCl}$ ( $\mathrm{pH} \mathrm{7.6)}, 5 \mathrm{mM} \mathrm{MgCl}_{2}, 2 \mathrm{mM}$ DL-isocitrate, $0.2 \mathrm{mM}$ NADP and $100 \mu \mathrm{l}$ enzyme extract in $3 \mathrm{ml}$. The second contained only the buffer and $100 \mu l$ enzyme extract. The difference in the NADP reduction rate between the two assays was used to calculate isocitrate dehydrogenase activity. Activity of cytochrome $c$ oxidase was determined by the rate of oxidation of reduced cytochrome $c$ measured by $A_{550}$, using a dual wavelength spectrometer (Shimadzu UV 3000). The assay medium contained $10 \mathrm{mM}$ potassium phosphate buffer $(\mathrm{pH}$ 6.9), $1 \mathrm{mM}$ EDTA, $5 \mu \mathrm{M}$ reduced cytochrome c and $50 \mu 1$ enzyme extract.

Polyohenol oxidase activity was measured by the rate of $\mathrm{O}_{2}$ consumption in $3 \mathrm{ml}$ of $0.1 \mathrm{M}$ Tris- $\mathrm{HCl}(\mathrm{pH} 8.0)$ containing $20 \mathrm{mM}$ phloroglucinol. The measurement was started by the addition of $100 \mu$ l enzyme extract using an oxygen electrode (Rank Brothers Engineering, England). Air-saturated distilled water was used to take a standard of the oxygen level at $237 \mu \mathrm{M}$ at $30^{\circ} \mathrm{C}$. The oxygen electrode was also used for the determination of catalase activity. The activity was measured by the rate of $\mathrm{O}_{2}$ liberation after $50 \mu$ l enzyme extract addition into the assay medium containing 0.1 $\mathrm{mM}$ potassium phosphate buffer $(\mathrm{pH} 7.2)$ and $6 \mathrm{mM} \mathrm{H}_{2} \mathrm{O}_{2}$ in $4.05 \mathrm{ml}$. Activity of peroxidase was determined by the rate of oxidation of guaiacol measured spectrophotometrically by $\mathrm{A}_{470}$. The assay medium contained $40 \mathrm{mM}$ acetate buffer ( $\mathrm{pH} 4.0), 1 \mathrm{mM}$ guaiacol, 4.7 $\mathrm{H}_{2} \mathrm{O}_{2}$ and $50 \mu \mathrm{l}$ enzyme extract in $2.7 \mathrm{ml}$.

All the above enzyme assays were carried out at $30^{\circ} \mathrm{C}$ except that for cytochrome c oxidase at $25^{\circ} \mathrm{C}$. Each of the seed samplings and enzyme extractions was duplicated except for isocitrate dehydrogenase activity with no duplication, and there was little difference between the first and second samplings in the pattern of change in enzyme activities. One representative data is shown in the following. Total protein content in the crude enzyme extracts was determined by Bio-Rad Protein Assay Kit using bovine $\gamma$-globulin as a standard.

The specific activity of an enzyme used here was defined as units of the enzyme activity per mg of the total protein content.

Ethanol Determination. One hundred of both dormant and non-dormant seeds were imbibed and sampled by a procedure identical to the above for the enzyme extracts. The samples were homogenized in $2 \mathrm{ml}$ of cold acetone and centrifuged at $32,000 \mathrm{xg}$ for $30 \mathrm{~min}$. Two $\mu 1$ of the resulting supernatants was injected into a gas chromatograph (Shimadzu GC-7A) equip- 
ped with a flame ionization detector. The column used was a $0.32-$ by $210-\mathrm{cm}$ coiled glass column pack with Porapak Q (50-80 mesh). Temperatures of the injection port and column oven were 250 and $200^{\circ} \mathrm{C}$, respectively. Supplies of nitrogen, air and hydrogen were $50 \mathrm{ml} / \mathrm{min}, 0.6 \mathrm{~kg}-\mathrm{cm}^{2}$ and $0.7 \mathrm{~kg} / \mathrm{cm}^{2}$, respectively. Ethanol excreted into the imbition water was also quantitatively determined by injecting $2 \mu$ l of water directly to the gas chromatograph. No determination was done for ethanol vaporizing from the seeds and imbibition water since our preliminary trial had shown that the amount was negligible when compared with those in seeds and excreted. Data were the mean of duplicated sampling.

\section{Results and Discussion}

The seed materials used for the respiration measurement and enzyme extraction showed relatively uniform germination (Figure $1 \mathrm{~A}$ and B), and in particular, the latter seeds showed highly synchronized germination : $88 \%$ of the seeds protruded the shoot and coleorhiza during 12 to $24 \mathrm{hr}$ in the imbibition, and 100\% had root growth at $48 \mathrm{hr}$. As a nature of weeds, weed seeds often exhibit germination over a long period even under a laboratory condition. This asynchronized germination makes physiological data difficult to interprete because in such an experiment we have to handle a batch of seeds with individual variation in the speed of germination. From this point of view, the seed samples of Echinochloa oryzicola VAsing. used here were appropriate to analyze for respiration and enzyme activities. No germination was observed in the dormant seeds for either respiratory measurement or enzyme extraction.

Patterns of the changes in the respiration are shown in Figure 2. The dormant seeds rapidly increased both $\mathrm{O}_{2}$ uptake and $\mathrm{CO}_{2}$ liberation during the first $12 \mathrm{hrs}$, and then after reached a plateau with little change. The

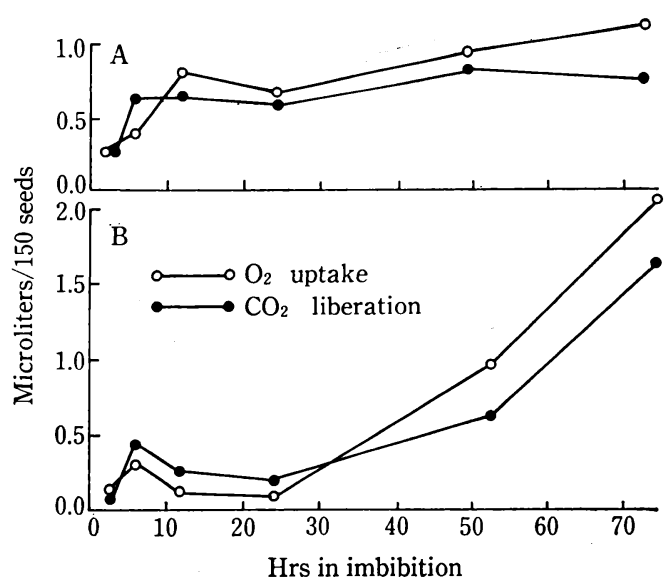

Fig. 2. Pattern of the change in $\mathrm{O}_{2} / \mathrm{CO}_{2}$ exchange of the dormant (A) and non-dormant seeds (B) of Echinochloa oryzicola under the imbibition at $30^{\circ} \mathrm{C}$ in the light.

non-dormant seeds also increased respiration up to $6 \mathrm{hr}$, but then decreased for once until $24 \mathrm{hr}$. During the period from 12 to $24 \mathrm{hr} \mathrm{CO}$ liberation exceeded $\mathrm{O}_{2}$ uptake, and the respiratory activity in $\mathrm{CO}_{2} / \mathrm{O}_{2}$ exchange was twoto four-fold smaller than that of the dormant seeds. After this period the $\mathrm{O}_{2}$ uptake rose almost continously throughout germination. The plateau in $\mathrm{O}_{2}$ uptake from 12 to $24 \mathrm{hr}$ appeared to end about the time when the seed coats were broken and free gas exchange started as pointed out for pea seeds (SPRAGG and Yemm, 1959; Mayer and Poljakoff-Mayber, 1982). Protrusion of the shoot and coleorhiza started about $48 \mathrm{hr}$ in some seeds (Figure 1A). The $R Q$ values calculated are shown in Figure 3. The values were near 3.0 for non-dormant seeds at the respiratory plateau from 12 to 24 $\mathrm{hr}$. RQ values are often related to the substrate oxidized in respiration. But, as evidence by the increased activity of alcohol dehydrogenase and ethanol formation during the period prior to the protrusion of the shoot and coleorhiza (Figures 4 and 5), these increased $\mathrm{RQ}$ values were due to $\mathrm{CO}_{2}$ liberation from the alcohol fermenation; the caryopsis may be so compactly enclosed by the floral lemma and glumes that it is hardly allowed to respire the external 


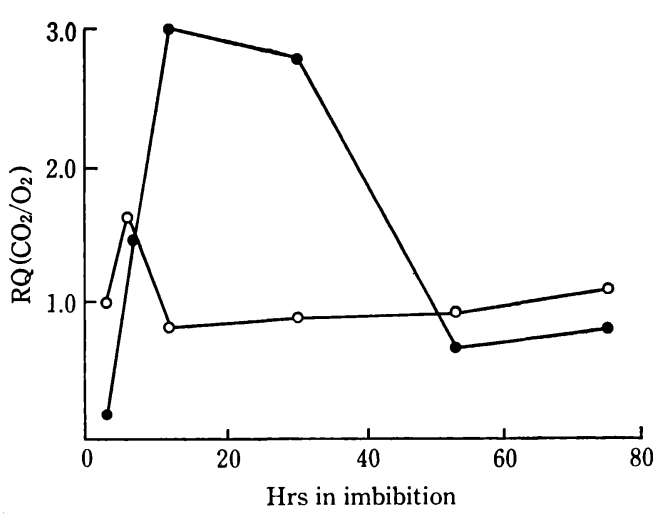

Fig. 3. Change of the dormant $(\bigcirc)$ and non-dormant seeds (O) of Echinochloa oryzicola in RQ during the imbibition at $30^{\circ} \mathrm{C}$ in the light.

$\mathrm{O}_{2}$ to satisfy the increased energy requirement for germination before breakage of the outer barriers.

Pattern of the change in the respiratory enzyme activities of the dormant and nondormant seeds is shown in Figure 4. The activity is expressed by a relative activity on percent basis using the largest activity of a sample as 100 . In the non-dormant seeds before imbibition at $30^{\circ} \mathrm{C}$ the activity of glucose-6phosphate dehydrogenase was almost two-fold higher than that in the dormant seeds, and increased continuously throughout germination, whereas in the dormant seeds the activity decreased to the initial level after an increase for once from 6 to $12 \mathrm{hr}$. The activity of 6 phosphogluconate dehydrogenase changed in a pattern similar to the preceding enzyme in the non-dormant seeds. Patterns of changes in these two enzyme were almost identical to those found in dormant and non-dormant seeds of Avena fatua (Kovacs and Simpson, 1976). Glucose-6-phosphate dehydrogenase is the regulatory enzyme for the oxidative pentose phosphate pathway that Roberts and Smith (1977) pointed out for the metabolic control in loss of seed dormancy. Early involvement of this pathway has been commonly reported for seed germination of various species including $E$. oryzicola during anaerobic germination (KEN-
NEDY et al., 1980).

There was no significant change either in alcohol dehydrogenase or cytochrome $c$ oxidase during $48 \mathrm{hrs}$ in the dormant seeds (Figure 4). However, in the non-dormant seeds these two showed contrasting patterns of activity changes. Activity of the former enzyme rapidly increased up to $12 \mathrm{hr}$ and then decreased sharply to almost nothing at the end of imbibition. The period from 12 to $24 \mathrm{hr}$ coincided with the time when the shoot and coleorhiza broke the puter barriers (Figure 1). In contrast, the activity of cytochrome $\mathrm{c}$ oxidase started to increase from $24 \mathrm{hr}$. These two enzyme activity patterns suggested that at about $24 \mathrm{hr}$ there was a transient phase in the respiratory pathway from alcohol fermentation to the conventional electron transport chain. In the dormant seeds the rate of gaseous exchange was virtually unchanged after an initial increase due to the exposure to $30^{\circ} \mathrm{C}$ and the $\mathrm{RQ}$ values were maintained at nearly 1.0 (Figures 2 and 3). Thus, it appeared that the seeds respired mainly through the conventional electron transport chain.

During $48 \mathrm{hrs}$ in imbibition no change were observed in the activities of polyphenol oxidase, catalase and peroxidase in the dormant seeds (Figure 6). In the non-dormant seeds, activities of these three oxidases increased continuously and reached a level about two-fold higher than those in the dormant seeds at 48 hrs imbibition. The role of polyphenol oxidase was indicated in seed dormancy of several species in relation to the seed coat impermeability to water and oxygen. Mature seeds of wild pea (Pisum elatius) have seed coats rich in o-dihydroxyphenols and impermeable to water, and germinate only after abrasion, but no such requirement exists for the cultivated pea ( $P$. sativum) (MARBACH and MAYER, 1975). Catechol oxidase, a polyphenol oxidase, rises sharply during seed development and dehydration of the wild pea, and the contact between the oxidase and its substrate was 

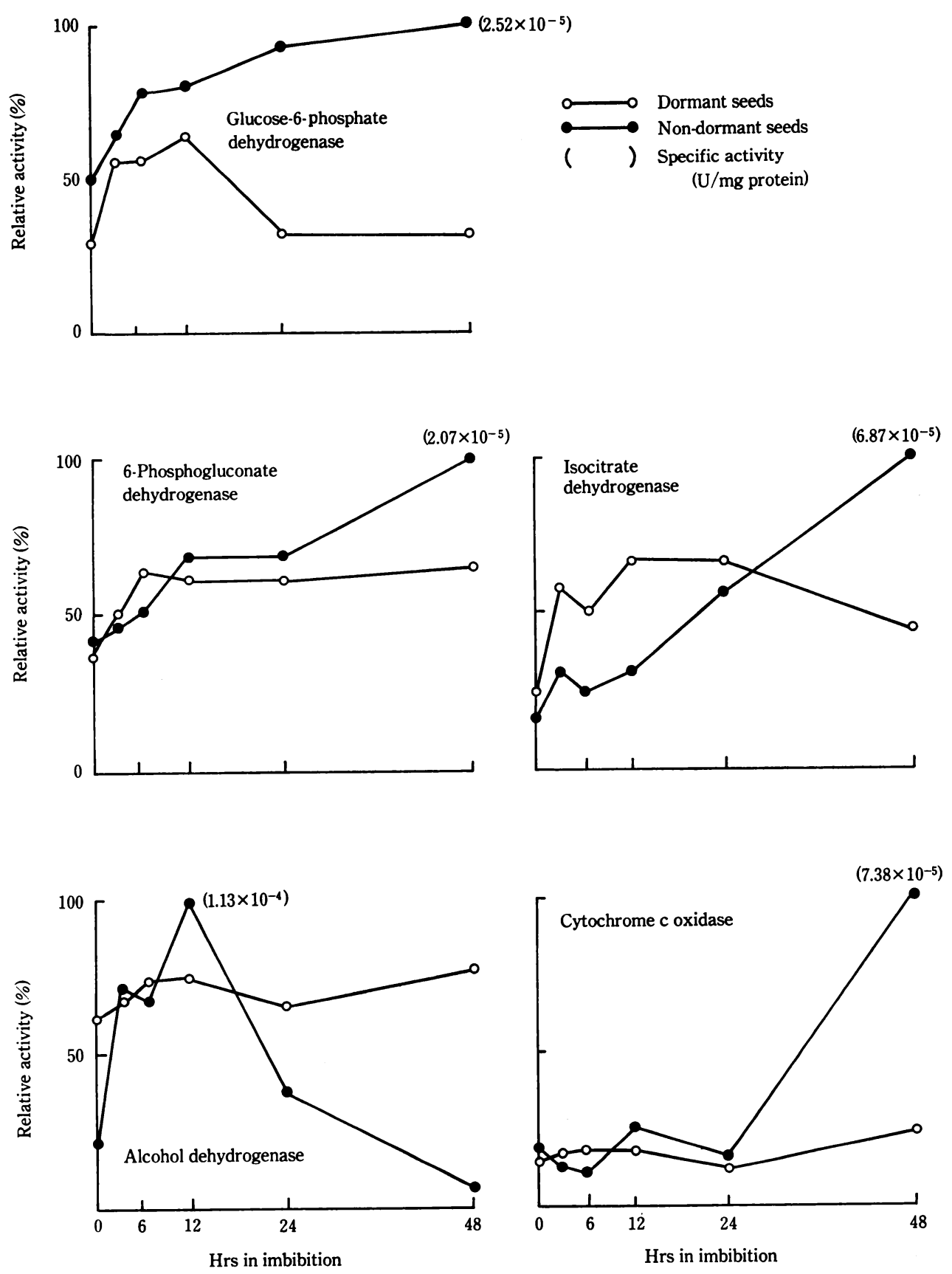

Fig. 4. Pattern of the change in respiratory enzyme activities of the dormant and non-dormant seeds of Echinochloa oryzicola during the imbibition at $30^{\circ} \mathrm{C}$ in the light. The relative activity was calculated on the $\%$ basis of the largest activity being 100 . 


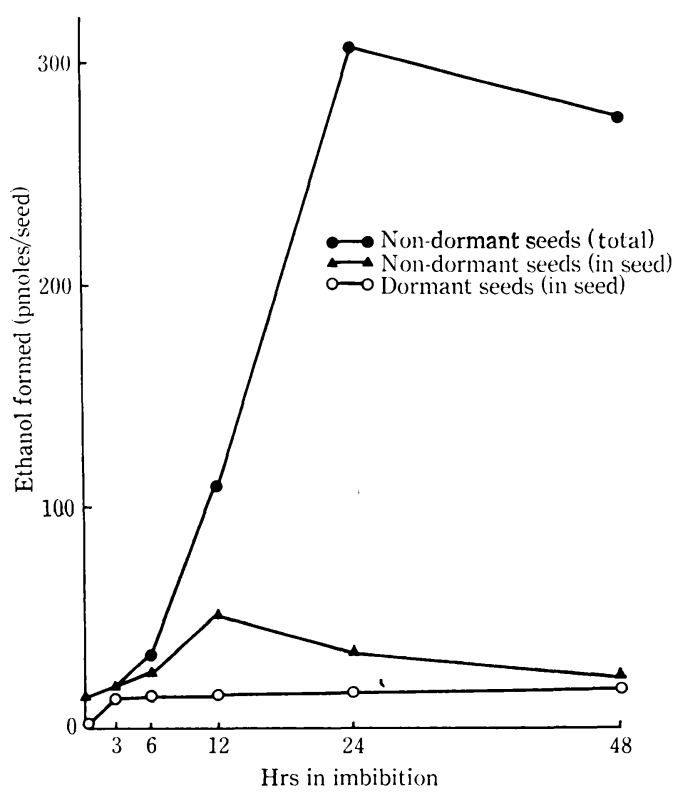

Fig. 5. Pattern of the change in ethanol formation by the dormant and non-dormant seeds of Echinochloa oryzicola during the imbibition at $30^{\circ} \mathrm{C}$ in the light. Seeds and imbibition water were analyzed separately. No detectable ethanol was found in the imbibition water with the dormant seeds.

suggested to be enhanced by rupturing of the cell membrane. But such a control mechanism of germination was lost in the cultivated pea. In $E$. oryzicola, the non-dormant seeds had lower activity of polyphenol oxidase than the dormant seeds at $0 \mathrm{hr}$ (Figure 6), and the polyphenol content of dormant seeds gradually decreased as the level of dormancy decreased (Yamasue and UeKI, unpublished). Also, the dormancy could be broken with $\mathrm{KCN}$, an inhibitor for the copper-containing enzyme (SHIMIZU and UEKI, 1972). Thus, it might be indicated that the reaction between polyphenol oxidase and its substrates had a role in a loss of the seed dormancy in regard to the seed coat impermeability to water and/or oxygen. But, this may not be the case since the seed coat impermeability to water did not appear to be a causal factor of the dormancy and the nondormant seeds showed anaerobic germination (Yamasue et al., 1985 ; Yamasue and UeKI,
1986).

Catalase is usually regarded as a detoxifying enzyme to break $\mathrm{H}_{2} \mathrm{O}_{2}$ down to $\mathrm{H}_{2} \mathrm{O}$ and $\mathrm{O}_{2}$ in aerobic organisms, and peroxidase also does so in the presence of electron donors such as phenols and amines (BeEvers, 1961). In Amaranthus albus L. and Lactuca sative L., catalase and peroxidase activity were assayed and found to increase during seed germination (Hendricks and Taylorson, 1974). From the fact that thiourea, sodium nitrite and hydroxylamine salts, which break seed dormancy of the species, inhibit the activity of catalase in extracts of the seeds. HENDRICKS and TAYLORSON (1974) suggested for the mechanism of germination promotion by these chemicals that metabolically derived hydrogen peroxide, spared from decomposition by catalase inhibition, oxidized reduced NADPH required as the oxidant in the pentose pathway. In the dormant seeds of $E$. oryzicola, the specific activity of catalase was thousands-fold higher than that of peroxidase (Figure 6). When the localization is disregarded, it is therefore suggested that $\mathrm{H}_{2} \mathrm{O}_{2}$ derived was broken down mainly by catalase rather than peroxidase in the seeds. If the shift of $\mathrm{H}_{2} \mathrm{O}_{2}$ breakdown to peroxidase is important for loss of dormancy as suggested by the above authors, the catalase activity smaller in the non-dormant seeds than in the dormant seeds (Figure 6) might be worth noting. In fact, $\mathrm{KCN}$, which is remarkably effective in breaking dormancy of this species, inhibited catalase and increased peroxidase activity in vivo before germination (HASEgAwA et al., 1986).

Objective of the experiments reported herein was to characterize the dormant and nondormant seeds of Echinochloa oryzicola in respiration and its related enzyme activity. In the dormant seeds, there were virtually no changes observed in either the gas exchange or enzyme activity throughout the imbibition period, and the seeds were quite quiescent in every aspect determined. However, activities of the enzyme 


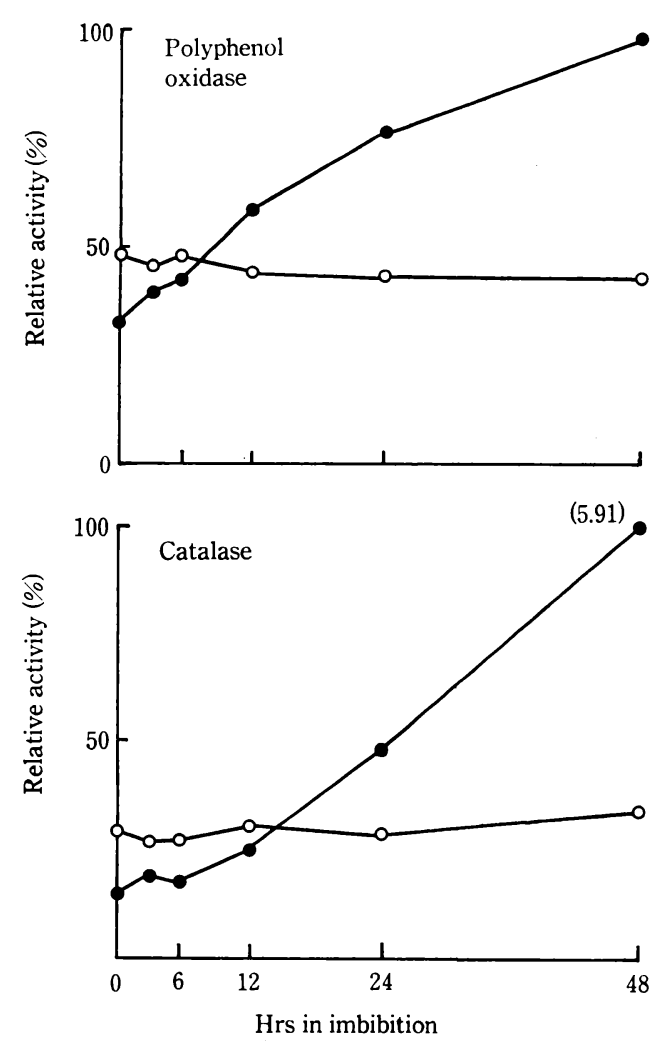

$\left(8.03 \times 10^{-1}\right)$

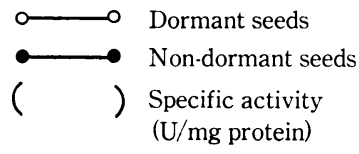

(U/mg protein)

Fig. 6. Pattern of the change in oxygen-related enzyme activities of the dormant and non-dormant seeds of Echinochloa oryzicola during the imbibition at $30^{\circ} \mathrm{C}$ in the light. The relative activity was calculated on the \% basis of the largest activity being 100 .

of the enzyme assayed, alcohol dehydrogenase in particular, were relatively high when compared with those of the non-dormant seeds at $0 \mathrm{hr}$. This may indicate that those enzymes were pre-existing, not a limiting factor in the activity per se and the enzyme operations were somehow blocked in vivo as seen by little ethanol production even at a high activity of alcohol dehydrogenase in vitro (Figures 4 and 5). In the non-dormant seeds, it was apparent that the seeds respired through alcohol fermentation prior to the protrusion of the coleoptile and/or coleorhiza which would expose the true seed (caryopsis or fruit) to the external oxygen, and after this protrusion the respiratory pathway was shifted to the conventional electron transport chain linked to the Krebs cycle. Thus, we could characterize the non-dormant seeds as those having the ability to satisfy the energy requirement for the embryonic growth alcohol fermentation at the early stage of germination. In addition, the fluctuation of alcohol dehydrogenase activity observed (Figure 4) appears to be partially regulated by a proteinaceous inactivator present in the seeds (Yamasue and UeKI, unpublished) as in seedlings of Oryza sativa L., Zea mays L. and Psium sativa L. (Suzuki and Kyuwa, 1972 ; Ho and Scandalios, 1975 ; Shimomura and Beevers, 1983). But, since the majority of seeds of Echinochloa oryzicola germinate in fields under flooded water deficient in oxygen, further evidence is required of the importance of anaerobic respiration for growth of the coleoptile and radicle under an oxygen deficient condition, and we also need to clarify the behavior of 
catalase and glucose-6-P dehydrogenase during the transient period from the dormant to non-dormant state in both laboratory and field soils.

\section{Summary}

As the flrst part of a series of experiments to elucidate the ecophysiological mechanisms of seed dormancy and germination of Echinochloa oryzicola VAsING., and observation was made through respiration and several enzyme activities during imbibition at $30^{\circ} \mathrm{C}$ in the light. Those determined were the pattern of changes of the dormant and non-dormant seeds in $\mathrm{CO}_{2} / \mathrm{O}_{2}$ exchange, ethanol production and activities of $\mathrm{G} 6 \mathrm{PDH}, 6 \mathrm{PGDH}, \mathrm{ADH}, \mathrm{ICDH}$, cytochrome c oxidase, polyphenol oxidase, catalase and peroxidase. In the dormant seeds, there were virtually no changes observed throughout the imbibition period, and the seeds appeared to respire to a small extent through the conventional electron transport chain since the $R Q$ values were maintained at nearly 1.0. However, in the non-dormant seeds both RQ values and ADH activity increased sharply until protrusion of the coleoptile and/or coleorhiza, and after this period cytochrome c oxidase activity started to increase throughout germination and the $R Q$ values approached 1.0. It was, therefore, suggested that the non-dormant seeds respire through alcohol fermentation during the early imbibitional period, and then through the conventional electron transport chain after the breakage of the outer barriers. The sharply increased activity of $\mathrm{ADH}$ observed at an early stage of imbibition could be a key metabolic character prior to the visible sign of germination : protrusion of the coleoptile and/or coleorhiza.

\section{References}

1) Beevers, J. : "Respiratory Metabolism" Pow, Peterson \& Co., Illinois, pp. 65-82 (1961).

2) Hasegawa, R., Y. Yamasue and K. UeKI (1986) : Mechanism of dormancy breaking with $\mathrm{KCN}$ in seeds of Echinochloa oryzicola VASING. - Verification of the HENDRICKS and TAYLORSON's scheme [in Japanese]. Weed Res. (Japan) 31 (Suppl.), 167168.

3) Hendricks, S. B. and R.B. Taylorson (1974): Peomotion of seed germination by nitrate, nitrite, hydroxylamine, and ammonium salts. Plant Physiol. 54, 304-309.

4) Ho, D.T. and J.G. Scandalios (1975) : Regulation of alcohol dehydrogenase in Maize scutellus during germination. Plant Physiol. 56, 56-59.

5) KАTAOKA, T. and S. Y. KIM (1978): Oxygen requirement for seed germination of several weeds [in Japanese, English summary]. Weed Res. (Japan) $23: 9-12$.

6) Kennedy, R., S. C.H. Barret t,D. V. Zee and M.E. Ruмpно (1980): Germination and seedling growth under anaerobic conditions in Echinochloa crus galli (barnyardgrass). Plant, Cell and Environ. 3, 243-248.

7) Kovacs, M. I. P. and G. M. Simpson (1976) : Dormancy and enzyme levels in seeds of wild oats. Phytochemistry 15, 455-458.

8) $M_{A R B A C H}$, I. and A. M. MAYER (1975) : Changes in catechol oxidase and permeability to water in seed coats of Pisum elatium during seed development and maturation. Plant Physiol. 56, 93-96.

9) Mayer, A. M. and A. Poljakoff-Mayber: "The Germination of Seeds" 3 rd ed. pp. 123-130, Pergamon Press, Oxford (1982).

10) Miyahara, M. (1972) : Physiological and ecological studies on dormancy of the seeds of Echinochloa crus-galli BeAuv. var. oryzicola OHwI, a paddy field weed. J. Cent. Agr. Expt. Sta. No. $16,1-62$.

11) NAS : "Weed Control" pp. 6-33, National Academy of Sciences, Washington, D.C. (1968).

12) Roвеrts, E.H. and R.D. Smith : Dormancy and the pentose phosphate pathway. In "The Physiology and Biochemistry of Seed Dormancy and Germination", ed. by A.A. KHAN. pp. 385-411,Elsevier/ North-Holland Biomedical Press (1977).

13) Shimizu, N. and K. Ueki (1972) : Studies on the breaking of dormancy in barnyardgrass seed, II. Change of the dormancy-breaking effect of several inhibitors against oxidation-reduction system by dormant stage [in Japanese, with English 
summary]. Proc. Crop Sci. So. Japan 41, 480-487.

14) Shimomura, S. and H. Beevers (1983): Alcohol dehydro genase and an inactivator from rice seedings. Plant Physiol. 71, 736-741.

15) SpragG, S. and E. W. Yemm (1959): Respiratory mechanisms and the change of glutathione and ascorbic acid in germinating peas. J. Expt. Bot. 10, 409-425.

16) Suzuki, Y. and K. KyUWA (1972) : Activation of alcohol dehydrogenase in germinating pea cotyledons. Plant Physiol. 27, 121-125.

17) Yamasue, Y., R. Hasegawa and K. Ueki (1985) :
On dormancy breaking with alcohols in seeds of Echinochloa oryzicola Vasing [in Japanese]. Weed Res. (Japan) 30 (Suppl.), 63-64.

18) Yamasue, Y. and K. UeKI (1979) : On dormancybreaking effect on Echinochloa oryzicola seeds by the closed imbibition [in Japanese]. Weed Res. (Japan) 24 (Suppl.), 99-100.

19) Yamasue, Y. and K. UeKI (1986) : Involvement of alcohol fermentation in seed germination of Echinochloa oryzicola $\mathrm{V}_{\text {ASING [in Japanese]. Weed }}$ Res. (Japan) 31 (Suppl.), 169-170.

(Received December 22, 1986)

\title{
タイヌビェ種子の休眠と発芽
}

一呼吸および呼吸関連酵素活性の変動

\author{
山末祐二・植木邦和 京都大学農学部 \\ 千坂英雄 農林水産省農林水産技術会議
}

\section{摘 要}

タイヌビェ種子の休眠・発芽に括ける生態的挙動に対する生理・生化学的機構（physiological ecology or ecophysiology）を解明しょらとする研究の第一歩として, 休眠および休眠覚醒種子の生理的特徵を呼吸およびその関連醭素 の活性から検討した。供試種子は農研センタ一鳰巣試験地由来のタイヌビェから採集したもので, 休眠種子は採種 後 $-21^{\circ} \mathrm{C}$ に貯蔵してその休眠性を維持させ，またこの一部の種子を $4^{\circ} \mathrm{C}$ 土壤埋没処理によって休眠覚醒種子を得た (Figure 1)。測定項目は $30^{\circ} \mathrm{C}$, 明条件の発芽床に置床したときの $\mathrm{CO}_{2} / \mathrm{O}_{2}$ 交換, エタノール生成, 呼吸関連酵素 $(\mathrm{G} 6$ PDH, 6PGDH, ADH, ICDH, cytochrome c oxidase, polyphenol oxidase, catalase, peroxidase) 活性の変動であっ た。休眠種子は置床全期間を通じて $\mathrm{CO}_{2} / \mathrm{O}_{2}$ 交換量, すべての酵素活性においてほとんど変動がなく, 呼吸代謝的に あ全く静止状態にあると考えられた。また， RQ 值が 1.0 付近に維持され，cytochrome c oxidase 活性も低いレベル で存在することから (Figures 3,4), 休眠種子は通常の電子伝達系で僅かながら好気呼吸していることが示唆された。 しかし，測定された酵素の活性 (Figures 4,6), とくに ADH 活性は休眠覚醒種子の置床 $0 \mathrm{hr}$ に比べ比較的大きく， 休眠種子内では酵素活性そのものが制限要因でなく，何らかの機作で酵素反応が静止しているものと考兄られた。

しかし，休眠覚醒種子に执いては，置床直後から RQ 值, ADH 活性などが急激に増大し (Figures 3,4), 多量のエ タノールが生成されるが (Figure 5), その後䩗葉, 根䩗の突出によって外被が破られ外部酸素が利用可能となると $\mathrm{ADH}$ 活性は低下し，代って cytochrome c oxidase 活性が増大し始め, RQ 值も 1.0 亿近づいた (Figures 3,4)。乙 たがって，休眠覚醒種子は花被，果皮などを含む外被によって胚に対する酸素の供給が制限されて特り，置床後から 䩗葉などの突出までの幼芽の生長に必要なェネルギーはアルコール発酵系によって獲得されることが示唆され，この 置床初期に拈ける $\mathrm{ADH}$ 活性の急激な増減は発芽の肉眼的観察以前におこる重要な生理的形質と考学られた。 